\title{
REWRITING THE NIGERIAN NATION AND REIMAGINING THE LESBIAN NIGERIAN WOMAN IN CHINELO OKPARANTA'S UNDER THE UDALA TREES (2015)
}

\author{
REESCRIBIENDO LA NACIÓN NIGERIANA Y \\ REIMAGINANDO LA MUJER NIGERIANA \\ LESBIANA EN LA OBRA DE CHINELO OKPARANTA \\ UNDER THE UDALA TREES (2015)
}

\author{
ARIADNA SERÓN NAVAS \\ Universidad de Sevilla \\ arisernav@alum.us.es
}

\begin{abstract}
This paper presents a revised paradigm of the postcolonial Nigerian nation through the exploration of the figure of the black lesbian in Nigeria. I argue that the reconceptualisation of Nigerian nationhood is enabled through the revision by Chinelo Okparanta in her debut novel Under the Udala Trees (2015) of subaltern and abject Nigerian womanhood carried out from a homoerotic or Afroqueer standpoint. The exploration of lesbian Nigerian woman(hood) from a literary stance clearly represents a valuable and subversive way of re-writing, re-constructing and re-conceptualising the postcolonial Nigerian nation so that othered subjectivities can also become part of the nation-building project. Okparanta, considered an Afrosporic and transcultural writer, interpellates the Nigerian nation in order to present us with post-abyssal configurations that transcend reductive and monolithic discourses. Drawing on the work of a wide array of scholars belonging to Postcolonial, Gender and Queer Studies — such as Neville Hoad, Ifi Amadiume, Lindsey Green-Simms, and Lee Edelman- I demonstrate how Okparanta's novel can work as an example of resistance against hegemonic, heteronormative and Eurocentric representations of Africa.
\end{abstract}

Keywords: Lesbian Nigerian woman(hood), Chinelo Okparanta, same-sex desire, postcolonial nation, Afroqueerness. 


\section{Resumen}

Este artículo tiene como propósito presentar un nuevo paradigma de la nación postcolonial nigeriana a través de la exploración de la figura de la mujer negra y lesbiana en Nigeria. Discutiré cómo la reconceptualización de la condición de nación de Nigeria se hace posible a través de la revisión que la autora Chinelo Okparanta hace de la feminidad nigeriana (subalterna y abyecta en este caso) desde una perspectiva homoerótica o afroqueer en su novela Under the Udala Trees (2015). La exploración de la mujer nigeriana y lesbiana desde una perspectiva literaria claramente propone una forma valiosa y subversiva de reescribir, reconstruir y reconceptualizar la nación nigeriana (postcolonial), con el propósito de que otras subjetividades instaladas en la otredad puedan formar parte del proyecto de construcción de la nación. Okparanta, considerada escritora afrodiaspórica y transcultural, interpela a la nación nigeriana para así mostrar configuraciones post-abismales de la misma que trascienden discursos reduccionistas y monolíticos. Haciendo uso de los planteamientos propuestos por intelectuales pertenecientes al campo de los Estudios Postcoloniales, de Género o Estudios Queer como Neville Hoad, Ifi Amadiume, Lindsey Green-Simms o Lee Edelman, pretendo demostrar que la novela de Okparanta puede funcionar como práctica de resistencia contra representaciones hegemónicas, heteronormativas y eurocéntricas del continente africano.

Palabras clave: Mujer lesbiana nigeriana, Chinelo Okparanta, deseo homosexual, nación postcolonial, identidad afroqueer.

\section{Introduction}

The African-American artist Roy DeCarava (1919-2009), well-known for his black-and-white photographic portraits of black America in post-war Harlem, helped to explore and construct a very particular African-American identity through his works depicting Harlem inner city. "Sun and Shade" (1952), one of his most iconic pictures, exhibits two black kids playing in a common space separated by dark and light, each of them inhabiting different halves. The symbolism of DeCarava's photograph is reflected in what this article tries to address, namely the coming together of somehow opposing realities in the same physical locus, inhabited by black subjectivities that remain in common yet welldifferentiated areas. In this article, I address same-sex attraction in post-war Nigeria as experienced by a number of homosexual female fictional characters who remain part of a society which still does not acknowledge or accept queerness as an undeniable dimension of the Nigerian nation. The exploration of lesbian Nigerian woman(hood) from a literary stance offers a valuable and subversive way of re- 


\section{Rewriting the Nigerian Nation}

writing, re-constructing and re-conceptualising the Nigerian post-nation so that othered subjectivities can also be recognised as part of the nation-building project. Though framed within a matrix of hatred, intolerance and persecution, lesbianism can be regarded as a form of resistance against colonial and heteropatriarchal structures that still permeate the modern African nation, as illustrated in the debut novel Under the Udala Trees (2015), written by the US-based Nigerian author Chinelo Okparanta.

Nowadays, homosexuality is criminalised in 29 out of the 54 countries in Africa. For instance, Botswana is the most recent country to repeal (in 2019) laws that had legally legitimised criminalisation and violence against same-sex relations, according to Amnesty International. ${ }^{1}$ Kenyan researcher Lyn Ossome aptly underlines that the change towards the democratisation of African states "creat[ed] visibility around queer activism and class" (2013: 32). However, this was also a contradictory period since there were, at the same time, several "wave[s] of competing fundamentalist and moralistic claims" (2013: 32). These democratising processes along with the current surfacing of gay and lesbian human rights have exposed the difficulties in theorising about these identities as they are often regarded as "a relic of the colonial past that must be transcended" or even as "a sign of the transnational future that must be feared" (Hoad in Ossome 2013: 33). Ossome also states that current debates about the de-criminalisation of same-sex and consensual relations are easily manipulated by "those hegemonic groups in society that have real access to resources and power", which is why in a myriad of present-day African countries "sexual identity is sacrificed at the altar of conservative religious or ethnic identities that are being positively manipulated for political and economic mileage" (2013: 44). Furthermore, Western religious and colonial beliefs support a very specific political and sexual agenda in which criminalising laws are passed as a result of the mythic conception that homosexuality and transsexuality are both un-African and un-Biblical imported realities from colonial times. In this novel, Okparanta delves into lesbianism as expressed during and after the Nigeria-Biafra civil war (1967-1970) in an effort to debunk these mythic conceptions. Before analysing the novel, I examine the notions of gender and sex in pre-colonial Nigeria to explore the impact (post-)colonialism has had in the (re-)conceptualisation of these two categories.

\section{Same-Sex Practices in Pre-Colonial Africa}

Gender in pre-colonial Africa was a flexible, dynamic system, never exclusively conditioned by biological sex, as Nigerian scholar Ifi Amadiume demonstrated in her path-breaking volume Male Daughters and Female Husbands: Gender and Sex in an African Society (1987). In this ethnographic study of the Igbo women 
belonging to the town of Nnobi, Amadiume examined the presence of what we have come to know as "male daughters", or women who had "the status of a son and [were] able to inherit [their] father's property" due to the absence of closer male members of the lineage (2015: 32). This flexible gender system "affected women's access to economic resources and positions of authority and power through the institutions of 'male daughters' and 'female husbands" resulting in role and status ambiguity (2015: 51). Indeed, women-to-women marriage (or "female husbandry") was a fairly common practice carried out as a means or strategy for women to free themselves from "domestic service" and thus achieve power and success (2015: 70). ${ }^{2}$ The post-1900 period saw the invasion of the Igbo hinterlands by the British, which was followed by the violent suppression of indigenous institutions, the imposition of Christianity and Western education, and the introduction of a new economy and local government administration through the warrant chief system. Western worldviews and belief systems entailed strong sex and class differentiation supported by rigid gender constructions; a woman was always female regardless of her social achievements or status (2015: 119).

As a result, a male-dominated and theocratic system was imposed on the colonies under British control. Moreover, Victorian notions of womanhood "idealized the virtuous and frail-minded female incapable of mastering 'masculine' subjects like science, politics and business" (Amadiume 2015: 136). This made feasible the total exclusion of women from the political and administrative spheres, forcing them into the role of "second fiddle". Eurocentric binary thinking was enforced as a form of domination that privileged Western conceptions - which included a heteropatriarchal and binary understanding of sexual desire and gender - and rejected African experience, characterised by flexibility in the understanding of gender and sexual orientation.

In explaining the way homosexuality was signified and experienced in pre-colonial Africa, researcher Chantal Zabus states that there already existed specific expressions to designate homosexuality in this continent before the colonial period, but that these practices " $\mathrm{d}[\mathrm{id}]$ not always designate homosexuality as it is understood and experienced in the Western world" (2013: 16). Zabus provides an example of same-sex relationships between men in many Melanesian ethnic groups as a rite of passage and not as a form of homosexual desire as theorised by the West.

An older man inseminating a young man or smearing the latter's body with ejaculate is an age-structured, intergenerational, possibly 'homosocial', form of sexuality, which allows a young man to access the world of adult — heterosexual- masculinity. If, in Western societies, homosexuality is divorced from reproduction, this is not the case by far in pre-colonial or post-colonial African societies. In pre-colonial Africa, young boys who had relationships with older men almost always married a woman later in life and had children. (2013:26) 
Zabus also mentions the "male-male non-penetrative" practice of "boy-wifery" and "mine marriages" in regions in South Africa (2013: 37-39). This is not to say that homosexuality, conceived as a sexual and/or romantic relationship between two same-sex partners, did not occur in pre-colonial Africa. Authors like Ifi Amadiume (2015), Chantal Zabus (2013), Kenneth Chukwuemeka Nwoko (2012), or Charles Ngwena (2018), among others, demonstrate how pre-colonial discursive theorisations of man, woman, husband, wife, heterosexual and homosexual in Africa deviated from the European ontological resignifications of these entities.

\section{Same-Sex Desire in Contemporary Nigerian Fiction}

I will centre my analysis on the ways queerness is expressed in twenty-first century Nigerian fiction and how queer Nigerians thrive in a hostile environment still reluctant to accept alternative gender and sexual manifestations. Indeed, Nigerians who dare to come out inevitably experience prejudice, criminalisation, (self-) censorship, physical and mental abuse, exile or even murder. Non-conforming gender and sexual identities are punished in most African countries by imprisonment (up to fourteen years), corrective (gang) rape, lynching, flagellation, ostracism, murder or even the death penalty (in the northern provinces of Nigeria, which are under Islamic Shari'a law). According to Edward Ou Jin Lee, "[c]olonial laws that criminalized sexual and gender transgressions (i.e. sodomy, 'eunuchs', vagrancy, etc.) operated as a key tool of white/Western empire building to contain and control the colonized" (2018: 65). He further argues that "[ $t]$ he policing, surveillance, and erasure of Indigenous sexualities and genders, as interpreted by colonial powers, served as key mechanisms through which many Indigenous societies were reorganised", concluding that "[ $t]$ he boundaries of heterocisnormative intimacies demarcated which sexualized and gendered behaviours and colonized bodies would be consigned to life and death [which] consolidated the colonial relation of the civilized (heterosexual/cissexual) white/ Western subject versus the uncivilized perverse Other" (2018: 65). Such a dual notion of civilised as implying heterocisnormativity and savage as identified with Other in any of its understandings was central to the nation-building project that Western metropolises imposed on the different countries in the Global South (see Hoad 2006).

In Nigeria, the Same-Sex Marriage Prohibition Act (SSMPA) — commonly called the "jail the gays" Bill — was passed and enforced in 2014 by the then-president Goodluck Jonathan. This bill was created to resist moral corruption by prohibiting "deviant unions" — typified as sodomy, abomination or perversion- and arresting, imprisoning or even executing people who dare to come out and express their 
homo-/transsexuality. Authors such as Adriaan Van Klinken and Ezra Chitando have acknowledged the fact that this legislation was "largely driven by religious agendas" (2016: 1), more specifically, fundamentalist agendas that welcome certain forms of Pentecostal Christianity. This interpenetration between religion (namely the Islamic Shari'a law and Pentecostalism) and politics is very evident in the Nigerian context where religious orthodoxy "has played an important role as a governance structure and mechanism" (Ukah 2016: 22), which deliberately contributes to the criminalisation of dissident sexualities.

In this bleak scenario, several artists and activists belonging to different generations and from different fields such as literature, cinema, sculpture, photography or journalism have represented and discussed these alternative subjectivities to proactively encourage a move towards a more accepting and modern vision of the Other in terms of desire and gender. There is a considerable repertoire of literary works whose main characters are fundamentally Afroqueer, ${ }^{3}$ for instance: Wole Soyinka's The Interpreters (1965), Ama Ata Aidoo's Our Sister Killjoy (1977), Mariama Bâ's Scarlet Song (1981), Yulisa Pat Amadu Maddy's No Past, No Present, No Future (1997), Unoma N. Azuah's Sky-High Flames (2005), Jude Dibia's Walking with Shadows (2006), Chimamanda Ngozi Adichie's short story collection The Thing around Your Neck (2009), Chris Abani's Graceland (2004), Chike Frankie Edozien's Lives of Great Men: Living and Loving as an African Gay Man (2017), Azeenarh Mohammed, Chitra Nagarajan and Rafeeat Aliyu's collection of memoirs She Called Me Woman: Nigeria's Queer Women Speak (2018), and the novel discussed in this section: Chinelo Okparanta's Under the Udala Trees (2015).

Twenty-first century Nigerian writers ${ }^{4}$ have introduced more diverse, antihegemonic discourses in order to explore the multiple manifestations of homoerotic desire from a positive, non-monolithic and anti-essentialist perspective. When it comes to the specific featuring of lesbian characters in present-day (sub-Saharan) literary narratives, we should not forget that this is still an emergent literary trend (Azuah 2005). Lindsey Green-Simms contends that all the current literary responses condemning homophobia and other forms of hatred against the LGBTQI+ community point to "an overall trend in much of anglophone [sic] sub-Saharan Africa where anti-gay legislation and rhetoric is on the rise" (2016: 141). For this reason, the term 'emergent' is fundamentally used in this literary context to "resist the dominant in ways not previously done before and to tell diverse stories about same-sex desire that are neither monothematic nor moralistic" (2016: 142).

In this vein, Chinelo Okparanta subscribes to this emergent literary trend with her two published works: her short story collection Happiness, Like Water (2013) and her aforementioned debut novel. In fact, most symbolic explorations of women's 
same-sex desire have traditionally taken place within the form of the short story (Adetunji Osinubi 2018: 673). However, Okparanta is one of the pioneers (along with others such as Unoma N. Azuah or Lola Shoneyin) to use the novel as a genre not only devoted to the exploration of male same-sex desire but rather as a means to explore lesbian subjectivity in a nuanced, sympathetic manner (Munro 2017). Okparanta's queering of the African novel is also exemplified in her attempt to normalise and humanise these subjectivities, while positively re-inscribing them into the Nigerian nation-building project. As this author explains in the "Author's Note" placed at the end of the text under scrutiny, "[t]his novel attempts to give Nigeria's marginalized LGBTQ citizens a more powerful voice, and a place in our nation's history" (2015: 325).

When delineating the differences in the ways lesbianism and womanhood have been portrayed by African writers belonging to different generations, Dobrota Pucherova asserts that "[third-generation] African lesbian fiction brings an entirely new perspective on African womanhood that has been essentialized by firstgeneration African academic feminists" (2019: 107). In relation to the inclusion of non-conforming sexualities in the African imaginary along with the revision of essentialised notions of wo/manhood, ma-/paternity and femininity/masculinity, Pucherova further argues that third-generation female authors

reject not only the notion that lesbianism is foreign to Africa, but also the definition of African femininity as centered around motherhood, wifehood, and self-sacrifice that has been affirmed even by theorists who have not explicitly rejected lesbianism. (2019: 110)

Thematically, this re-signification of Nigerian femininity in twenty-first century queer Nigerian fiction is not complete without re-defining the traditional, nuclear African family and heterocisnormative African society (Pucherova 2019: 109). Lesbian women are no longer reductively depicted as "intimate friends" having a Platonic relationship, or as having a mother-like, childish relationship (2019: 109). On the contrary, lesbian desires and needs are fully recognised and explored in contemporary African fictional works, and lesbian characters may as well oppose the idea of aligning their personal desires and aspirations with the making of a conventional family. As the same scholar puts it, referring to the protagonists in African lesbian fictional works,

by orienting their desire toward other women, the heroines of this fiction reject the traditional family that has been at the center of African nationalist imagination and express a desire for a new model of the nation that is nonviolent, protective of human freedom and of nature, and moved forward by respect for others rather than identity politics, the imperative of procreation, or the capitalist idea of progress. (Pucherova 2019: 111) 
These manifestations are nothing less than artistic activism aiming to shift the status quo of the homosexual citizen, to avoid the removal of non-normative subjectivities and to bring in a renegotiated paradigm of the twenty-first century (queer) African.

\section{Lesbian Intimacies, Nationhood and Nigerianness as Explored by Chinelo Okparanta}

Third-generation Nigerian author Chinelo Okparanta (1981-) was born in Port Harcourt and raised in Pennsylvania. She is currently an Assistant Professor of English and Creative Writing at Bucknell University, where she is also a Faculty Research Fellow. She has been nominated, shortlisted and awarded with several distinctions such as the 2014 and 2016 Lambda Literary Award for Lesbian General Fiction for her debut short story collection Happiness, Like Water (2013) and her novel Under the Udala Trees, the 2014 New York Public Library Young Lions Fiction Award, and the 2017 International DUBLIN Literary award. Under the Udala Trees (2015) is her first Anglo-Igbo novel. ${ }^{5}$ This coming-of-age novel or bildungsroman (see Courtois 2018) explores a number of dichotomies such as past vs. present, mother (heterosexual) vs. daughter (homosexual), tradition vs. modernity, or African vs. Western worldviews. The dichotomous nature of the novel is very much connected with Okparanta's personal circumstances, particularly when labelled as an Afrosporic author. As she explains in an interview,

I'm working within an African literary tradition in the sense that the culture is very strong in my writing. My novel is completely set in Nigeria. [...] I wanted we as Nigerians to have this conversation on our own, because there is sometimes too much Western influence or Western pressure trying to tell Africans "what to do" and "how to be" and how to run our countries. [...] What's happening in Nigeria, for instance, is there's a crisis between honoring our traditional belief systems and wanting strongly to feel like we are part of the West, that we can do the West better than the West can do itself. (In Lombardi 2018: 19-20)

Okparanta, considered as a mediator between different cultures, is able to confront both perspectives in the same fictional space to critically engage in the exploration of colonialism and its impact on a number of socio-cultural and political structures and conceptions in Nigeria, in this case, mainly related to gender and sexual preference. In her analysis of the novel, Okparanta negotiates the main character's subaltern position in postcolonial, post-bellum Nigeria together with the author's own status as a peripheral, Afrosporic Nigerian.

Under the Udala Trees, articulated around six main sections and an epilogue, is, at its core, a rethinking of the relationship between the Nigerian woman and nation 


\section{Rewriting the Nigerian Nation}

beyond Western notions of gender and sexual normativity. Indeed, what we see here is a masterful use of the inward gaze which provides a detailed analysis of the protagonist's inner world and emotional landscape while showing "levels of detail and intimacy previously unseen" in the coming-out African novel (Green-Simms 2016: 144). This bildungsroman deals with the figure of the lesbian in modern Nigeria as described by a first-person female narrator from an un-stigmatising narrative position. Such retrospective meditation on the protagonist's lesbian awakening is interesting as it allows her to come to terms with her own queerness without explicitly outing herself. The protagonist's homosexual orientation is not overtly revealed, but her queerness is subtly voiced through her actions and inner thoughts in the novel. In this sense, Ijeoma remains a "closeted lesbian" despite the fact that the novel implicitly "outs" her. This formal aspect, I argue, reflects the tensions and contradictions in contemporary coming-out narratives that arise from "those modes of privacy and publicness that are more complex than 'out' or 'closeted", as Lindsey Green-Simms and Brenna Munro assert (2018).

The story begins with Ijeoma, the protagonist, living with her parents in Ojoto (Southeast Nigeria) during the Nigeria-Biafra civil war (1967-1970). ${ }^{6}$ In fact, the author based the fictive construction of the novel's setting on her mother's testimonies from the war and on real material such as old newspapers and photographs, old radio announcements, BBC documentaries and a number of interviews (Carter Wood 2016: 30). Taiwo Adetunji Osinubi posits that the choice of this war setting for Anglo-Igbo authors works as a metafictional space employed "to examine [and work through] all manners of marginalization and disaffections created by political authority and their dissemination into private lives" (2018: 678). Symbolically, this conjuring up of spectral and traumatic national episodes enables, on the one hand, the creation of a fictional queer archive when inscribing the queer dimension into a rather turbulent period in recent Nigerian history; and, on the other, the interrogation of "the coherence of projected [post-]nations", solidly tying "Nigeria's violent and disordered pluralisms to the suppression of lesbian emergence in the public domain and in the home space" (2018: 677).

Drawing attention to the notion of "intersecting struggles" put forth by Lindsey Green-Simms in an African context (2016: 139), we can easily notice the interconnectedness of national and personal trauma, as in this prophetic passage at the beginning of the novel:

By this time [1968], talk of all the festivities that would take place when Biafra defeated Nigeria had already begun to dwindle, supplanted, rather, by a collective fretting over what would become of us when Nigeria prevailed: Would we be stripped of our homes, and of our lands? Would we be forced into menial servitude? Would we be reduced to living on rationed food? How long into the future would we have to bear the burden of our loss? Would we recover? (Okparanta 2015: 4) 
This sort of meditation on the future of the country, particularly from the retrospective position of a lesbian Igbo woman, is embedded in the current conception of queer individuals in present-day Nigeria. In this vein, a parallel between the persecution and discrimination of Igbos during the war and the persecution and criminalisation of LGBTQI+ subjects in this country can be easily traced. Okparanta successfully examines the intersecting space between the protagonist's ethnicity and her queerness. In fact, this attests to the tensions between the ethnic-national, the familial and the personal, but also the temporal tensions between past and present.

In this narrative, a discursive revision of the post-nation during and after conflict is clearly staged. Nigerian individuals were forced to physically and symbolically reconstruct the postcolonial Nigerian nation and to negotiate the presence of subjectivities and sexualities that were considered a direct consequence of the British invasion. ${ }^{7}$ One of the aims of Anglo-Igbo Afrosporic writers is thus to allow a trans-generational and transnational dialogue in order to reformulate the postcolonial nation, which is exactly what Okparanta does: she includes the trope of the lesbian woman in a realistic post-war Nigeria that is regenerating itself; a country actively trying to detach itself from imperialist control. When connecting the Nigeria-Biafra civil war and the persecution of Nigerian queer subjects, Under the Udala Trees de-centralises hegemonic, colonial and heteropatriarchal conceptions of Nigeria by “'contaminating' national narratives with sexual transgressions" (Hayes 2000: 16). In this restorative project, the text provides readers with diversified forms of national belonging by rejecting the post-nation's homogenising endeavour.

Okparanta's novel challenges, by means of counter-hegemonic discourses, the articulations, systems and worldviews imposed by the Global North which especially affected the ontological re-signification of the African woman, doubly subalternised in a "process of racial inferiorization and gender subordination" (Oyewumi 1997: 124). As Cheryl Clarke lucidly asserts in her article "Lesbianism: An Act of Resistance", "[t]he lesbian has decolonized her body. She has rejected a life of servitude implicit in Western, heterosexual relationships and has accepted the potential of mutuality in a lesbian relationship — roles notwithstanding" (1981: 128, emphasis in original). In this vein, lesbianism can be seen in this novel as a subversive practice of contestation and resistance against heteronormativity, gender subjugation and colonial oppression. Notwithstanding, Ijeoma experiences and reproduces a different form of resistance against heteronormative and phallocratic Nigerian society. She passes first as a heterosexual woman to later exit, while defying, the so-called "heterosexual matrix" (see Wittig 1992, 1993). She cannot afford the privilege to out herself publicly, even 


\section{Rewriting the Nigerian Nation}

when she leaves her abusive husband, Chibundu, since she could easily be murdered, which is why she decides to maintain a covert romantic relationship with a woman, Ndidi, while raising her daughter to accept other forms of bonding and desire.

In this coming-of-age novel, the defeat of Biafra leads the protagonist's father, Uzo, to commit suicide and Ijeoma and her mother to relocate to another Nigerian town (Aba). When Ijeoma reaches adolescence, she is sent away to live with the grammar school teacher and his wife so that she can receive a formal Christian education while working as their house girl. In her stay with that family, Ijeoma (of the Christian Igbo ethnic group) meets Amina (of the Muslim Hausa ethnic group) and they become involved. ${ }^{8}$ During those two years of companionship under the grammar school teacher's roof, they have their first sexual encounters where they discover and explore their (homo)sexuality. Eventually, they get caught and both are forced to continue their education in a Catholic boarding school. There, Amina starts meeting boys and ends up marrying a Hausa man. Ijeoma, for her part, finishes her education and moves back in with her mother to help her with her small business. Ijeoma will then meet Chibundu, her future husband, and Ndidi - the "woman apart" as she is described in the story (Okparanta 2015: 221 ) — who will eventually become her lifelong lover.

Once Ijeoma reaches adulthood, she is forced to marry Chibundu. In so doing, she decides to stop seeing Ndidi (though they keep in touch by correspondence) and moves in with her husband with whom she has a daughter, Chidinma. The novel ends with the collapse of the marriage and Ijeoma and Chidinma moving back with Ijeoma's mother while renewing contact with her ex-lover Ndidi. This failure and critique of the normative family could allegorically stand for a projected image of contemporary Nigeria to "uncover the fiction of the nation" as conceived in an African post-colonial context (Adetunji Osinubi 2018: 677; see also Boehmer 2005).

Through the fictional character of Ijeoma, Okparanta advocates a Nigeria where men and, most especially, women can have a say in their own lives and whose desires are not constrained by external actors. Indeed, I would claim that the aim of this novel (and of this peripheral author) is to de-centre normative sexualities from marginal spaces in Nigeria (and in the world). This argument has been further developed by Chantal Zabus in her volume Out in Africa: Same-Sex Desire in Sub-Saharan Literatures and Cultures (2013), where she postulates:

The queer subject by definition speaks from the margins in that by virtue of his, her or his position as excluded, that subject's desire interrogates what the mainstream discourse of heteronormativity tries to conceal. In so doing, it produces —unwittingly or consciously - sites of resistance from which alternative models of subjectivity can be generated. (2013: 12) 
These "sites of resistance" can be seen as anti-colonial and post-abyssal routes against imperialist power structures in Africa and anti-patriarchal opposition to male-dominated societies worldwide.

We can find a number of examples of well-differentiated gender roles for men and women in Nigeria, which clearly expose the straitjacketed sexual division of labour where women are commonly conceived as procreative vessels. As Currier and Migraine-George state, "[1]esbians therefore become equated not only with an anti-nationalist agenda but also with the prospect of national corruption and collapse, underscored by the misconception that same-sex sexualities will lead to ethnic extinction" (2017: 143). This is an argument previously outlined by the intellectual Lee Edelman in his volume No Future: Queer Theory and the Death Drive (2004) in which he introduces the notion of "reproductive futurism", defined as that which "impose[s] an ideological limit on political discourse as such, preserving in the process the absolute privilege of heteronormativity by rendering unthinkable $[\ldots]$ the possibility of a queer resistance to this organizing principle of communal relationships" (2004: 2). As this scholar suggests, homosexual subjects challenge the heteronormative investment in this "reproductive futurism", "accepting its figural status as resistance to the viability of the social [and thus to futurity of human race]" (2004:3). In other words, a seemingly disassociated and queer temporality that would prevent homosexual subjectivities from taking part in any viable nation-building project. Edward $\mathrm{Ou}$ Jin Lee asserts in this regard that "[c]entral to the post-independence nationbuilding projects was the maintenance of a heterosexual, cissexual, and patriarchal social order, through discourses of 'family values', the promotion of heterosexual monogamous marriage, and continued criminalization of sexual and gender transgressions" (2018: 66). In line with these arguments, Okparanta, we could argue, clearly proposes a queer understanding of national futurity that does not go against the social, communal or ethnic viability of the Nigerian nation. In this light, Okparanta's novel does challenge African traditionalism and its cordonedoff, predestined conception of the queer self (especially the lesbian woman). Nonetheless, traditional and pre-colonial sexual practices to some degree inform Okparanta's narrative without her intentionally trying to restore or recuperate them in a non-fictional context. If anything, Afrosporic Okparanta, with her Anglo-Igbo novel, acknowledges the hybridity of a current national/social scenario where African roots are intertwined with Western influences.

In the novel, Ijeoma's mother reveals her own conception of the Nigerian woman and the gender roles she must play in this society. She declares repeatedly: "Marriage is for everyone! Remember, a woman without a man is hardly a woman at all. Besides, good men are rare these days. Now that you've found 
one, you must do what you can to keep him" (Okparanta 2015: 223, emphasis added). And then, she further develops this maxim: "Because sooner or later we would each become somebody's wife, and as wives, it would be our obligation to be fertile, to bear children for our husbands, sons especially, to carry on the family name" (Okparanta 2015: 310, emphasis added). These instances reveal the indoctrinating notions mostly passed from mothers to daughters to discipline the female body and the female mind and, more dangerously, the effect these teachings have on their daughters' overall development. Indeed, it is through these restrictive and infantilising patterns of interaction and socialisation that women acquire very specific formulations of womanhood that imply submissiveness, interdependence and lack of (homosexual) desire or pleasure. Even though there is collusion between Ijeoma's sense of womanhood and her mother's in the novel, Okparanta re-examines these dynamics and ventures to renegotiate and resist domestic notions of womanhood and female desire. Ijeoma un-does and re-does gender in Nigeria while re-staging nationhood in this postcolonial setting. Additionally, Ijeoma's daughter Chidinma enacts a more accepting attitude towards queer subjects, which underlines a change in the way current generations regard queerness and the many ways motherhood is performed in this novel.

Moreover, Ijeoma's mother constantly stresses that female subjectivity is understood not individually but relationally (i.e. in relation to her husband, offspring and community so that women can be easily assigned to a certain female category with well-delimited gender roles). In the following example, Ijeoma's mother advises her daughter to find a husband that can provide for her and "make her complete", as Amina has done recently: "Marriage has a shape. Its shape is that of a bicycle. [...] All that matters is that the bicycle is complete, that the bicycle has two wheels", to which she adds: "The man is one wheel' $[\ldots]$ 'the woman the other. [...] What is certain, though, is that neither wheel is able to function fully without the other. And what use is it to exist in the world as a partially functioning human being?'” (Okparanta 2015: 182). It is very interesting to observe how Ijeoma becomes a fully-functioning and empowered human being "through a lesbian sexuality" (Courtois 2018: 127).

In patriarchal and heterosexist societies, affective gender roles are automatically assigned to women and instrumental roles to men (see Hernando Gonzalo 2000). According to Asante L. Mtenje, "disciplining female bodies and positively channelling their sexual energies towards home and family and away from desire and bodily pleasure sets the foundations for the (re)productive project of building the nation" (2016: 192). In such societies, women are thus conceptualised as (affectionate and exploitable) "means" in themselves while men are treated like 
"ends", which is exactly what Ijeoma's mother is demanding from her daughter: finding a man, serving him, bearing him sons, and caring for the family just for the sake of perpetuating "tradition" and reinforcing that restricted sense of nationhood and Nigerianness. ${ }^{9}$ By questioning traditional, prescriptive gender norms, the protagonist actively demands to enact her agency so as to seek a life of her own choice. She deconstructs and reconstructs herself in an attempt to naturalise and legitimise alternative manifestations of womanhood, where agency and ownership are not taken away from women.

In fact, I would postulate that Ijeoma and her Mama can be held as opposing forms of understanding the Nigerian post-nation. Whereas Ijeoma's Mama is presented as a woman who epitomises the traditionalism, heterosexism, chauvinism and parochialism deeply ingrained in this society, Ijeoma is held as a symbolic representation, one of many, of the modern Nigerian nation that is more progressive and, certainly, more welcoming of other identitary and sexual expressions. Additionally, it cannot be overlooked how Okparanta's Afrosporic status challenges and unsettles the very foundations of Nigerianness and the Nigerian post-nation as discussed from a queer and transcultural standpoint.

\section{Conclusion}

In this article I have examined the lesbian paradigm in postcolonial Nigeria as a plausible form of re-wiring and re-writing the postcolonial African nation beyond abyssal and exclusive structures. Third-generation authors are creating multidimensional characters through which they can re-conceptualise personal, cultural, sexual and gender identity in Africa only to create more textured African subjectivities. The novel under scrutiny, among many others written by thirdgeneration African authors that explore similar thematic lines, tries to subvert traditional and conforming gender roles, heterocisnormative sexualities, and essentialised notions of womanhood and femininity while including alternative systems of representation which, I argue, pro-actively work towards an emancipatory re-negotiation of the African post-nation and, fundamentally, the re-imagination of the African (lesbian) woman. ${ }^{10}$ 


\section{Rewriting the Nigerian Nation}

\section{Notes}

1. For further information related to the mapping of anti-LGBT laws in Africa, see https://www.amnesty.org/en/latest/ news/2019/06/botswana-decriminalisation-ofconsensual-same-sex-relations-shouldinspire-other-african-countries/ and <https:// www.amnesty.org.uk/lgbti-lgbt-gay-humanrights-law-africa-uganda-kenya-nigeriacameroon.

2. As researcher Kenneth Chukwuemeka Nwoko reminds us, "the practice [of female husbandry] did not involve sexual relationship between the couple as opposed to lesbianism" (2012: 74). This claim has also been supported by authors such as Chantal Zabus (2013), Joseph M. Carrier and Stephen O. Murray (1998).

3. Most authors gathered in this list are Nigerian. However, I have included three African writers who are considered seminal figures due to the original way they have explored Afroqueerness and homoerotic desire in this continent. These authors are: Ghanaian Ama Ata Aidoo, Senegalese Mariama Bâ and Sierra Leonean Yulisa Pat Amadu Maddy.

4. As clarification, previous generations of sub-Saharan writers have addressed homosexuality and queerness in different ways. Lindsey Green-Simms mentions in this respect that homosexual characters who appeared in works written by first and second-generation Nigerian authors were "characterized above all by silence and opacity" (2016: 140), while the characters' agency was openly denied. Homosexuality was still considered taboo and homoerotic desires were viewed through a homophobic lens. Authors born after independence in Africa, or the so-called third-generation writers, have started to represent homosexuality in Nigeria from a more positive stance.

5. A number of discussions have traditionally been conducted by several African authors to accurately define African literature and why it is mostly written in a colonial or European language (for more information, see Achebe 1997, and Bandia 2012). Following Elena Rodríguez Murphy's postulates $(2015,2017)$ on the particular use of the English language in contemporary Nigerian literary texts, this novel can be defined as using a Nigerian English or, more specifically, as using a completely new variety of English in which authors add terms and expressions from their own African languages. In Under the Udala Trees, Okparanta introduces Igbo expressions throughout the text, an example of the literary and personal hybridity, interstitiality and transculturation of many thirdgeneration African authors nowadays.

6. This conflict was one of the most traumatic events for Nigeria and its effects are still prevalent nowadays. In 1960 after Nigeria gained independence from the British Empire, an ethnic group from the Northern part of the country, the Muslim Hausas, massacred the Christian Igbos in their area. The Igbos relocated to the Eastern part of Nigeria where this ethnic group was a majority. As the Nigerian government was ruled by the Hausa ethnic group, the Igbos decided to secede and establish the Republic of Biafra in 1967. After this event, civil war broke out concluding with the surrender of the Biafran government in 1970 due to the military superiority of the Nigerian state (see "Civil War Breaks out in Nigeria" 2009).

7. It is necessary to clarify the conception of the post-nation. Some contemporary authors have openly questioned and even given up on the idea of the postcolonial African nation, revealing its arbitrariness and fictionality. For instance, US-based Nigerian author Chigozie Obioma critically stated: "Today most of the nations in Africa should not even be called African nations, but western African nations. The language, political ideology, socio-economic structures, education, and everything that makes up a nation, even down to popular culture, do not originate from within these countries. African nations have a total dependency on 
foreign political philosophies and ideas, and their shifts and movements" (2017). In this line, Okparanta's novel could be held as a re-interrogation of the post-nation from a queer perspective as a thematic strategy to denounce the pervasiveness of neocolonial realities and their effects on national and personal spheres.

8. As mentioned above, during the civil war, the Igbo and the Hausa ethnic groups confronted each other and fought for control of the country. Ethnic and religious origin, along with gender, is another constitutive factor against this type of union in the novel.

9. As Remi Akujobi argued in relation to those patriarchal and prescriptive notions of womanhood and motherhood, "motherhood is the only thing in which a woman's worth is measured. A woman without a child is viewed as a waste to herself, to her husband and to her society" (2011: 5). He, thus, highlights the conception of women as nation-builders and, therefore, their "duty" to bear children in order to perpetuate society, community and nation.

10. The author wishes to acknowledge that the research and writing of this text has been funded by the Research Project PGC2018-095393-B-100 “Queer Temporalities in Contemporary Anglophone Culture (Literature, Film, Videogames)" approved by the Spanish Ministry of Science, Innovation and Universities, and supported by the Research Group "Escritoras y Escrituras" (Hum-753) from the University of Seville.
ACHeBE, Chinua. 1997. "The African Writer and the English Language". Transition 75/76 (18): 342-349.

AdetunjI OsinubI, Taiwo. 2018. "The Promise of Lesbians in African Literary History". College Literature: A Journal of Critical Literary Studies 45 (4): 675-686.

Aкujobl, Remi. 2011. "Motherhood in African Literature and Culture". CLCWeb: Comparative Literature and Culture 13 (1): 1-7.

Amadiume, Ifi. (1987) 2015. Male Daughters, Female Husbands. Gender and Sex in African Societies. London: Zed Books Ltd.

Azuah, Unoma N. 2005. "The Emerging Lesbian Voice in Nigerian Feminist Literature". Matatu 29-30 (1): 130-141.

BANDIA, Paul E. 2012. "Postcolonial Literary Heteroglossia: A Challenge for Homogenizing Translation". Perspectives: Studies in Translatology 20 (4): 419-431.

Boehmer, Elleke. 2005. Stories of Women. Gender and Narrative in the Postcolonial Nation. Manchester: Manchester U.P.
Carrier, Joseph M. and Stephen O. Murray. 1998. "Woman-Woman Marriage in Africa". In Murray, Stephen O. and Will Roscoe (eds.) Boy-Wives and Female Husbands: Studies in African Homosexualities. New York: Palgrave Macmillan: 255-266.

Carter Wood, Eden. 2016. "I Put my Lesbian Novel in the Nigerian President's Hands". Diva Magazine (February). <https://www.pressreader. com/uk/diva/20160201/281990376555935>. Accessed September 11, 2019.

"Civil War Breaks out in Nigeria". 2009. History.com (October 22) <https://www. history.com/this-day-in-history/civil-war-innigeria>. Accessed December 12, 2019.

Chukwuemeka Nwoko, Kenneth. 2012. “Female Husbands in Igbo Land: Southeast Nigeria". The Journal of Pan African Studies 5: 69-82.

Clarke, Cheryl. 1981. "Lesbianism: An Act of Resistance". In Moraga, Cherrié and Gloria Anzaldúa (eds.) This Bridge Called My Back: Writings by Radical Women of Color. New York: Kitchen Table Press: 128-137. 


\section{Rewriting the Nigerian Nation}

Courtols, Cédric. 2018. "'Thou Shalt Not Lie with Mankind as with Womankind: It Is Abomination!': Lesbian (Body-)Bildung in Chinelo Okparanta's Under the Udala Trees (2015)". Commonwealth Essays and Studies 40 (2): 119-133.

Currier, Ashley and Thérèse Migraine-George. 2017. “'Lesbian'/Female Same-Sex Sexualities in Africa". Journal of Lesbian Studies 21 (2): 133-150.

Edelman, Lee. 2004. No Future: Queer Theory and the Death Drive. Duke: Duke U.P

Green-Simms, Lindsey. 2016. "The Emergent Queer: Homosexuality and Nigerian Fiction in the $21^{\text {st }}$ Century". Research in African Literatures 47 (2): 140-161.

Green-Simms, Lindsey and Brenna Munro. 2018. "The Coming-Out of the African SameSex Novel". Africa Is a Country (September 7). $<$ https://africasacountry.com/2018/07/thecoming-out-of-the-african-same-sex-novel>. Accessed May 11, 2020.

HAYES, Jarrod. 2000. Queer Nations. Marginal Sexualities in the Maghreb. Chicago: University of Chicago Press.

Hernando Gonzalo, Almudena. 2000. La construcción de la subjetividad femenina. Madrid: Asociación Cultural Al Mudayna.

Hoad, Neville. 2006. African Intimacies: Race, Homosexuality, and Globalization. Minneapolis: University of Minnesota Press.

Lombardi, Bernie. 2018. “'Where Paradise Will Hopefully One Day Be': An Interview about Sexuality, Home, and Diaspora with Chinelo Okparanta". The Black Scholar 48 (3): 17-26.

Mtenje, L. Asante. 2016. “Contemporary Fictional Representations of Sexualities from Authoritarian African Contexts". PhD Dissertation. University of Stellenbosch.

Munro, Brenna. 2017. "States of Emergence: Writing African Female Same-Sex Sexuality". Journal of Lesbian Studies 21 (2): 186-203.

NgwenA, Charles. 2018. What is Africanness? Contesting Nativism in Race, Culture and Sexualities. South Africa: PULP.

Овіома, Chigozie. 2017. "Africa has been Failed by Westernisation. It Must Cast Off Its
Subservience". The Guardian (November 12). $<$ https://ww w.theguardian.com/ commentisfree/2017/nov/12/africa-failed-bywesternis ation-must-cast-off-its subservience>. Accessed May 12, 2020.

Okparanta, Chinelo. 2013. Happiness, Like Water. London: Granta.

OKPARANTA, Chinelo. 2015. Under the Udala Trees. London: Granta.

Ossome, Lyn. 2013. "Postcolonial Discourses of Queer Activism and Class in Africa". In Ekine, Sokari and Hakima Abbas (eds.) Queer African Reader. Nairobi: Pambazuka Press: 32-47.

Ou JIN LeE, Edward. 2018. "Tracing the Coloniality of Queer in Trans Migration: Resituating Heterocisnormative Violence in the Global South and Encounters with Migrant Visa Ineligibility to Canada". Canada's Journal on Refugees 34 (1): 60-74.

OYeWumI, Oyeronke. 1997. The Invention of Women: Making an African Sense of Western Gender Discourses. Minneapolis: University of Minnesota Press.

Pucherova, Dobrota. 2019. "What Is African Woman? Transgressive Sexuality in $21^{\text {st }}$ Century African Anglophone Lesbian Fiction as a Redefinition of African Feminism". Research in African Literatures 50 (2): 105-122.

Rodríguez Murphy, Elena. 2015. Traducción y literatura africana: multilingüismo y transculturación en la narrativa nigeriana de expresión inglesa. Granada: Comares.

Rodríguez Murphy, Elena. 2017. “New Transatlantic African Writing: Translation, Transculturation and Diasporic Images in Chimamanda Ngozi Adichie's The Thing Around Your Neck and Americanah". Prague Journal of English Studies 6 (1): 93-104.

UKAH, Asonzeh. 2016. "Sexual Bodies, Sacred Vessels. Pentecostal Discourses on Homosexuality in Nigeria". In Van Klinken, Adriaan and Ezra Chitando (eds.) Christianity and Controversies over Homosexuality in Contemporary Africa. Oxon: Routledge: 21-37.

Van Klinken, Adriaan and Ezra Chitando. (eds.) 2016. Public Religion and the Politics of Homosexuality in Africa. Oxon: Routledge. 
WittIG, Monique. 1993. "One Is Not Born a Woman". In Abelove, Henry, Michèle Aina Barale and David M. Halperin (eds.) The Lesbian and Gay Studies Reader. New York: Routledge: 103-109.

WITTIG, Monique. (1992) 2006. El pensamiento heterosexual y otros ensayos. Trans. J. Sáez and P. Vidarte. Madrid: Infoprint.
Zabus, Chantal. 2013. Out in Africa: Same-Sex Desire in Sub-Saharan Literatures and Cultures. New York: Boydell and Brewer.

Received: $13 / 02 / 2020$

Accepted: 17/09/2020 